\title{
Impact Properties of Self-Hardening Aluminium Alloy (Alzn10si8mg) at Elevated Temperatu- res
}

Eva Tillová, Mária Chalupová, Lenka Hurtalová, Juraj Belan Faculty of Mechanical Engineering, University of Žilina, Univerzitná 8215/1, 01026 Žilina. Slovak Republic. E-mail: eva.tillova@fstroj.uniza.sk

Self-hardening aluminium alloy AIZn10Si8Mg represents an innovative class of light aluminium alloys and they present high mechanical properties, which make them suitable for many applications in different industrial fields, especially in transport industry. The most important and relevant feature of the self-hardening alloys is related to their good performance, without the need of any heat treatment: they are subjected to a natural ageing phenomenon at room temperature after a storage period of about 7-10 days. The possibility to avoid the heat treatment represents an important benefit, contributing to considerably reduce both the production cost of some components and the amount of energy. Furthermore, without heat treatment the risk of component's deformation during the production is eliminated.

The Charpy impact energy of experimental cast alloy was measured at $-196^{\circ} \mathrm{C},-20^{\circ} \mathrm{C}, 20^{\circ} \mathrm{C}, 5^{\circ} \mathrm{C}, 100^{\circ} \mathrm{C}, 150^{\circ} \mathrm{C}$, $200^{\circ} \mathrm{C}, 250^{\circ} \mathrm{C}, 300^{\circ} \mathrm{C}, 350^{\circ} \mathrm{C}$ and $400^{\circ} \mathrm{C}$ in terms of the total absorbed energy. Effect of temperature to microstructural changes and fracture surface on the impact toughness was investigated. A combination different analytical techniques (light microscopy upon black-white etching, scanning electron microscopy (SEM) upon deep etching) were therefore been used for the identification of the various phases.

Keywords: aluminium cast alloy, microstructure, impact energy, fracture surface

\section{Acknowledgement}

The authors acknowledge the financial support of the projects VEGA No1/0533/15 and European Union - the European project ITMS: 26110230117 - "Promoting quality education and development of human resources in technological research and development in the area of modern knowledge-based society“.

\section{References}

[1] PEZDA, J. (2012). Heat Treatment of AlZn10Si7MgCu Alloy and its Effect on Change of Mechanical Properties. In: Archives of Foundry Engineering, Vol. 12 (2), pp. 135-138.

[2] PEZDA, J. (2013). Effect of T6 Treatment Parameters of AlZn10Si7MgCu Alloy on Change of its Hardness and Impact Strength. In: Archives of Foundry Engineering, Vol. 13 (1), pp. 143-146.

[3] TILlOVÁ, E., CHALUPOVÁ, M. (2009). Structural analysis (Štruktúrna analýza), Edis Žilina (in Slovak).

[4] TILlovÁ, E., CHAlupovÁ, M., HURTAlOVÁ, L., D́URINÍKOVÁ, E. (2011). Quality control of microstructure in recycled Al-Si cast alloys. In: Manufacturing Technology, Vol. 11, pp. 70-76.

[5] ĎURINÍKOVÁ, E., TILLOVÁ, E., CHALUPOVÁ, M. (2011). Phase and structure characteristics of recycled AlZn10Si8Mg cast alloy. In: Manufacturing technology, Vol. 11, pp. 11-17.

[6] TILLOVÁ, E., ĎURINíKOVÁ, E., CHALUPOVÁ, M. (2011). Structural analysis of secondary AlZn10Si8Mg cast alloy. In: Acta Metallurgica Slovaca, Vol. 17 (1), pp. 4-10.

[7] www.alurheinfelden.com

[8] VAŠKO, A. (2009). Analysis of the factors influencing microstructure and mechanical properties of austempered ductile iron. In: Communications. Vol. 4, pp. 43-47.

[9] BOLIBRUCHOVÁ, D., RICHTÁRECH, L. (2013). Effect of adding iron to the AlSi7Mg0.3 (EN AC 42 100, A356) alloy. In: Manufacturing Technology, Vol. 13, No. 3, pp. 276-281.

[10] BOLIBRUCHOVÁ, D., ŽIHALOVÁ, M. (2013). Possibilities of iron elimination in aluminium alloys by vanadium. In: Manufacturing Technology, Vol. 13, No. 3, pp. 289-296.

[11] TAYLOR J. A. (2004). The effect of iron in Al-Si casting alloys. In: $35^{\text {th }}$ Australian Foundry Institute National Conference, pp. 148-157, Adelaide, South Australia

[12] SEIFEDDINE, S. (2007). The influence of Fe on the microstructure and mechanical properties of cast Al-Si alloys. In: Literature review - Vilmer project. Jönköping University, Sweden

[13] MICHNA, Š., NÁPRSTKOVÁ, N. (2012). The Application of Fractography to Resolve the Issue of Castings Quality in the Automotive Industry. In: Manuf. and Ind. Eng., 11 (3), pp. 50-53.

[14] WARMUZEK, M. (2004). Aluminium/Silicon Alloys: Atlas of Microfractographs. Introduction to Aluminium Silicon Casting Alloys. 